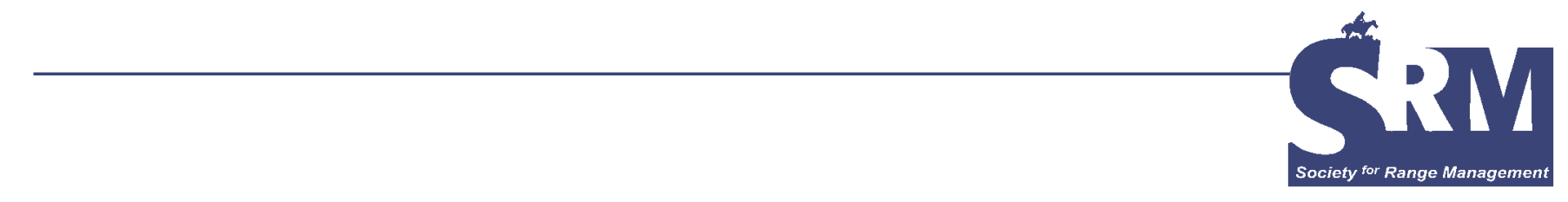

\title{
Wildfire's Place in Land Management: A Case Study
}

\section{Letting wildfire burn in select remote forest and rangelands is needed to increase plant community diversity and production, even with the risk of increased annual bromegrasses.}

\section{By Lee E. Hughes}

\section{Introduction}

Wildfire, generated by lightning, has a place in the ecosystems of our forests and ranges. Some range and forest lands contain wilderness and remote areas, which are large acreages free of human developments, where fires are allowed to burn. But there remain other remote lands and wilderness areas where fire is still suppressed. The continued suppression of these fires is questionable and worthy of discussion.

The Arizona Strip Field Office of the Bureau of Land Management implemented a modified suppression plan on the 3 million acres under its administration in 1981 (see Map). The fire plan had areas of pinyon-juniper, sage brush, and blackbrush that were managed in the fire plan as observation/modified suppression, which was a "let-burn" situation. Full/modified suppression occurred when fire was burning in the ponderosa pine, Mojave Desert, grasslands, and salt deserts, where immediate extinguishing of the fire was carried out.

In the beginning of the plan implementation, burning indexes were used to determine suppression efforts. The indexes were conditions, such as smoke dispersal, humidity, temperature, and wind, used to determine whether burning was allowable. "Observation" meant that the fire was merely watched and left to burn out on its own. "Modified suppression" meant letting an area burn to some boundary and then putting it out or putting it out depending on the fire indexes. "Full suppression" meant putting the fire out immediately. It was found, however, over a 3-year period, that too many

This article has been peer reviewed.

\section{Monitoring Methods}

Pace Frequency: This method involves using a 40-cm $\times 40-$ $\mathrm{cm}$ plot frame. The plot frame is placed 200 times in 4, 50pace transects or 2, 100-pace transects. At each placement, all herbaceous and woody species rooted in the frame are noted, along with the overhanging canopy of woody species. The result is the frequency of occurrence for each species.

Dry Weight Rank: This method is done concurrently with pace frequency (above). The species occurring in the plot frame are ranked by weight, and only the heaviest 3 species are noted. The heaviest is given a rank of 7 ; the next-heaviest, 2; and the third-heaviest, 1. From the calculations, species composition by weight is ascertained.

times fire had been suppressed, instead of letting them burn.

In the mid-1980s, a consensus was developed, and areas were designated either "full suppression" or "observation." The indexes were removed, and observation areas were allowed to burn in almost every instance of burning. The fires in full suppression areas, such the Mojave Desert, ponderosa pine, and grasslands, were extinguished as soon as possible. This strategy operated until the fall of 1988, when the plan was terminated, because of Yellowstone National Park's big fires, which occurred as a result of let-burn designation. The controversial Arizona Strip Modified Fire Suppression Plan was then put aside, and full suppression was implemented on most areas, including wilderness. 


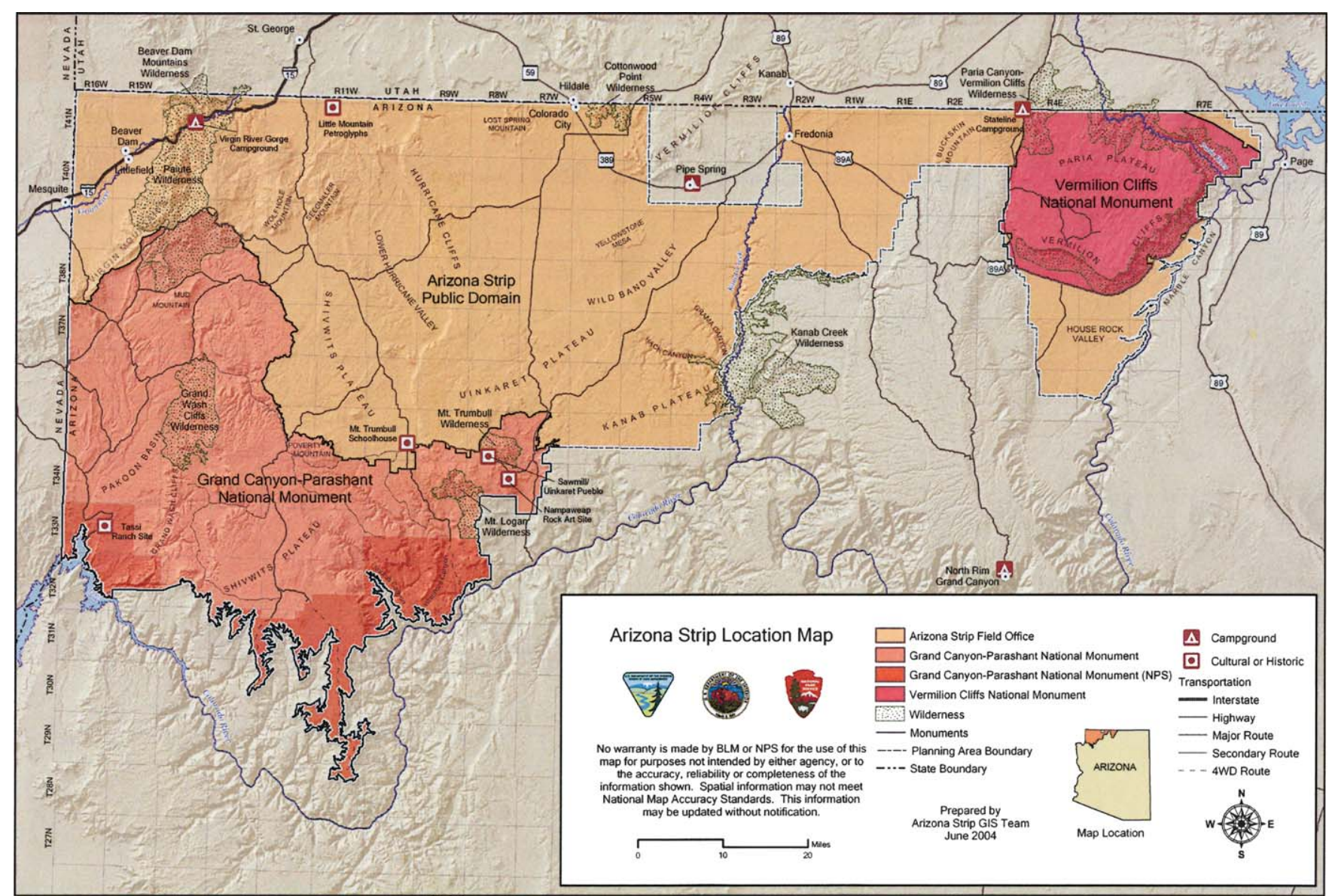

Mokaac Burn is located just north of Wolfhole Mountain. The Link Spring Burns are in the Grand Wash Cliffs Wilderness.

\section{How Much Was Actually "Let Burn"}

In the 8 years that the plan was in effect, a total of 654 acres burned under the observation ("let burn") policy. The total area burned in the observation (let-burn) and full suppression zones was 38,705 acres. The number of fires reported in the let-burn zones over the 8-year period amounted to 233 out of a total of 583 fires. The let-burn fires occurred in the pinyon-juniper forest and some in the blackbrush. Most of the let-burn fire acreage occurred in 1981, with 559 acres burned. The largest number of occurrences in the let-burn zone was 41, in 1986. These were mostly single trees. The range of let-burn fires was from 2 to 41 occurrences per year throughout the 8-year period.

\section{It Was a Time of Rain}

The years from 1978 to 1988 produced the longest string of more-than-100\%-of-average precipitation to occur since records started being kept in the 1960s on BLM-administered lands. Colorado City, Arizona, started gathering precipitation data in 1950, and their records also show that this 10 -year period had precipitation every year that ranged from $110 \%$ to $172 \%$ of average.

The years when the modified-suppression plan was in effect were wet. The plan was not tested in dry years.
Because of the wetness through those years, the amount burned in sagebrush, pinyon-juniper, and blackbrush was probably well below the burn potential. The ample moisture, however, allowed the Mojave Desert, where the creosotebush and Joshua trees are, to grow heavy, annual bromegrass crops. These areas burned in the 1980s, but this vegetation zone fell into the full fire-suppression area.

Precipitation from 1988 to 2004 was variable. A precipitation gauge in close proximity of the subject burns showed the following precipitation averages. From 1988 through 1992, the average precipitation ranged from $74 \%$ to $98 \%$. From 1993 through 1998, the precipitation ranged from 64\% to $151 \%$, with 4 years above $100 \%$ and 2 years below $100 \%$. In the 5 years from 1999 through 2003, there were 4 years below $100 \%$ and 1 year of above-average precipitation. The range was from $25 \%$ to $109 \%$ of average.

\section{The Argument Against "Let Burn"}

The opposition to let-burn plans in sagebrush, pinyonjuniper, blackbrush, and other vegetation types on the Arizona Strip was (and is) that fire allows the weedy, undesirable annual bromegrasses (ie, cheatgrass and red brome) to invade into the burned areas. This type of plant was (and is) undesirable because it's a flashy fuel when dry, and 
Table 1. Species composition or frequency of burns

\begin{tabular}{|l|c|c|c|c|c|c|c|}
\hline & $\begin{array}{c}\text { Year } \\
\text { burned }\end{array}$ & Year of reading & $\begin{array}{c}\text { Perennial } \\
\text { grass (N) }\end{array}$ & $\begin{array}{c}\text { Perennial } \\
\text { forbs (N) }\end{array}$ & Browse (N) & Shrubs (N) \\
\hline grass (E)
\end{tabular}

$\mathrm{N}$ indicates native species; $\mathrm{E}$, exotic species; est, estimate.

(1) Dry weight rank reading in 2004. 1984 reading was estimated from photos.

(2) Seeded, but seeded grasses did not survive. All this is native sand dropseed.

(3) There are 7 different native, nonseeded grasses-galleta, threeawn, muttongrass, squirreltail, blue grama, sanddrop, and a wheatgrass.

(4) Mostly seeded sand dropseed and side-oats grama.

reburns do occur where it dominates and is present in large quantities. Annual bromegrasses are present in many of these areas in small quantities and have the potential to increase as soon as the shrub cover is removed by fire. However, some newly burned areas are dominated by such native annuals as Indian tobacco, species of annual buckwheats, native penstemons, and the nonnative mullein, not annual bromes, but the argument against let-burn policies requires putting out the fires to prevent any chance of annual bromegrass increasing its coverage.

There were other reasons stated against let-burn plans. One was liability, but that issue failed to stand up under scrutiny because of the remoteness and little development in the vegetation zones under the observation area.

\section{The Reasons for "Let Burn"}

The argument for the use of wildfire was to improve the herbaceous and browse productivity in the pinyon-juniper, blackbrush, and sagebrush zones, to reduce fire suppression costs, to allow the role of fire to maintain a wide variety of plant communities, and to avoid hazardous-fuel build-up. Also, it was often difficult to meet all the conditions for a prescribed fire (ie, smoke dispersal in the atmosphere), so when a wildfire occurred in a proposed burn area, it was an opportunity to accomplish the otherwise stalled but needed burn.

\section{To Seed or Not to Seed}

After a fire burns, whether a let-burn or a full-suppression fire, the areas were generally, but not always, seeded by flying the seed onto the burn. When possible, drilling the seed on the burn was done, where topography allowed it. The topography seldom allowed drilling the seed, nor any covering actions, except to have cows trample the seed into the ground by having a herd move across a burned area.

There is no predicting how the seeding by any of the methods will do in the burned pinyon-juniper, blackbrush, and sagebrush sites. Generally, if favorable amounts of rains fall after seeding, the seeding will be successful, but not always, and if a drought period occurs following seeding, the chance for good seeding establishment evaporates. Drought is a frequent and often long-staying visitor to the Arizona Strip. Many, not all, acres of pinyon-juniper burns on the Arizona Strip have been seeded with poor to no results. The seeding gamble is high risk.

An occasional success has been encouraging. A seeding was done in 1998, in which seed was flown onto a 1,000-acre 
area. The seed, however, did not emerge, and instead, the area was blanketed with a thick cover of annual bromegrass. Nevertheless, in 2000-2001, after a wet winter and spring, a crop of several of the seeded species emerged in the thatch of the annual brome. Surprisingly, today, the intermediate wheatgrass, side-oats grama, and other native species are dominant, and the annual grasses are a minority, even after the current drought, which is in its sixth year.

Most other monitored areas that were seeded after fire, since 1998, have native and invasive annuals dominating because the drought has killed back or reduced the seeded and native perennials.

\section{The Questions}

The question is "How do these burns look today in relation to species present after 20+ years since the burn?" Are they dominated by annual bromes? How are the native plants doing? And if they had seed flown on, how are the seeded species doing after $20+$ years?

To answer the questions, 3 large burns were revisited - the Mokaac Burn and the Link Spring Burns. Mokaac was not seeded, and the 2 Link Spring Burns (Tweedie and Bench) were seeded to native grasses and nonnative wheatgrasses.

\section{A Return to the Sites Burned Mokaac}

The first fire that was let burn was the Mokaac, south of St. George, Utah, on Mokaac Mountain. It burned 419 acres of blackbrush over a 2-day period in early July 1981, before burning out. The burn was not seeded. Within 2 years, a crop of red brome covered the old burn. In 1984, I visited the mountain and took 3 aspect pictures of the red brome. In 2001 and 2004, I returned to the aspect and repeated the photographs; I also ran a species composition transect in the aspect area of the photos (Photos 1 and 2).

The lower part of the Mokaac Burn was composed of 37\% red brome in 2004 (Table 1), down from 100\% in 1984. The natives (primarily shrubs, browse, and forbs) accounted

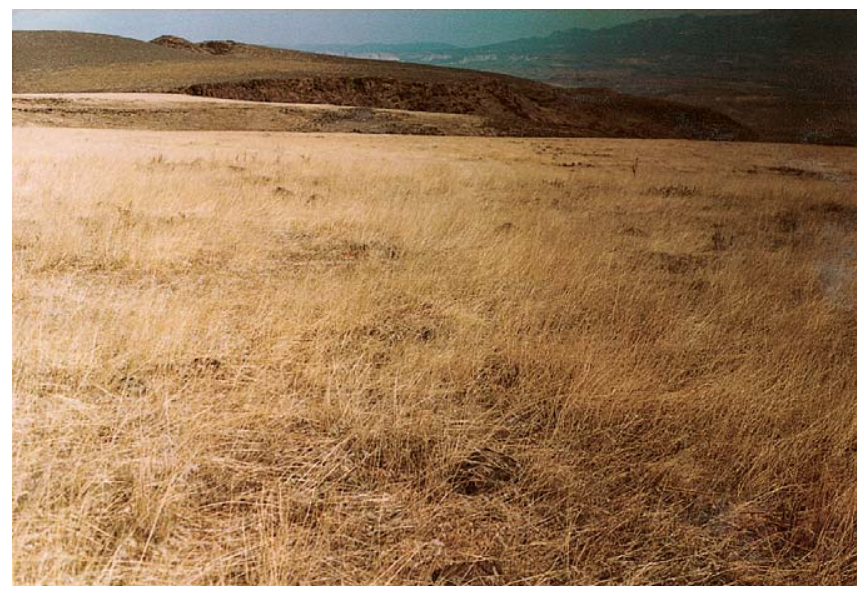

Photo 1. Mokaac Burn, in 1984; annual brome dominance. Precipitation was $103 \%$ of average. for $63 \%$ of the composition. So, native plants dominated in 2004. The upper part of the Mokaac Burn was also dominated by natives (mostly shrubs, browse, and forbs). Although this area was dominated by nonnatives in 1984, by 2004, the natives dominated almost exclusively in the transect.

\section{Link Spring}

Link Spring allotment has photographs from 1982 and 1983 along with pace-frequency transects and repeat transects of vegetation at trend key areas in its 2 burns (Table 1). One Link Spring Burn (Tweedie) occurred in the sagebrush plant community, and the other (Bench) was in the blackbrush/ pinyon-juniper community. The combined area of the 2 fires was about 2,000 acres, burned in 1980-1981. Both the Tweedie (sagebrush) and Bench (blackbrush) burn areas were seeded by air, with livestock-trampling as the only seedcovering activity. The Tweedie area responded poorly to the seeding, but the Bench area was most successful (Table 1). Also, the seeded and nonseeded perennial grasses on the Bench maintained themselves through the years, under fall-spring grazing, and had retained frequency levels of $25 \%$ in 1998. Annual bromes also had an abundant showing (Photos 3 and 4). Then, the drought started in 1998, and by 2004, the percentage of perennial grasses was one-fifth of the 1998 level.

The Tweedie part of Link Spring had a frequency of $75 \%$ red brome, but the natives had a frequency of $79 \%$ in 2003. Native and nonnative occurrence were equal, but natives have increased dramatically in quantity and diversity since the 1980s. The Bench fire area of Link Spring did not have annual bromes in the transects in the early 1980s. The seeded sand dropseed and side-oats grama totally dominated (Photo 3), but in 2003, annual bromes had increased to $42 \%$. Shrubs, like small rabbitbrush and snakeweed (both natives), had increased dramatically. Other shrubs, like cliff rose and desert peach, had also increased in the transect, but more

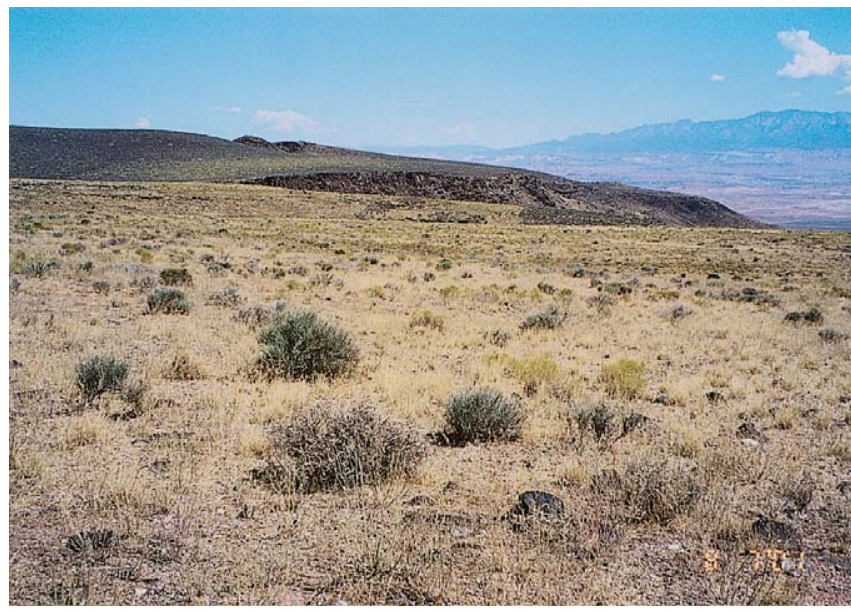

Photo 2. Mokaac Burn, in 2001; native shrubs, browse, and forbs dominating (mostly Mormon tea, globe mallow, and wolfberry). Precipitation was $119 \%$ of average. 


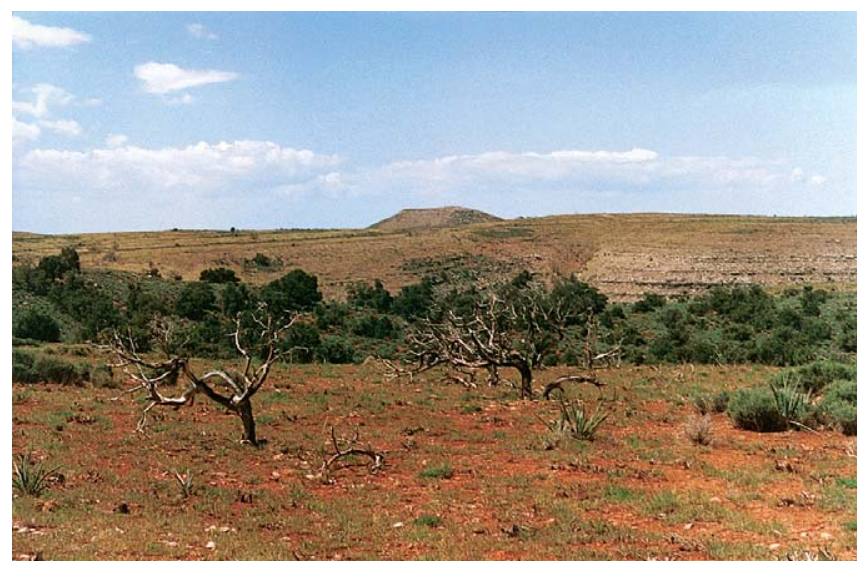

Photo 3. Link Spring Bench Fire, in 1983; successful seeding; note: no annuals. Precipitation was $146 \%$ of average.

modestly. The natives, as shown in Table 1 , were dominant by a small margin in the Bench Burn in 2003.

The shrubs and browse appear to be increasing in Link Spring and Mokaac, and if no reburns occur, will probably dominate in the next 20 years. Preventing any reburns at this stage of succession is important and is where suppression efforts pay off ecologically.

\section{Grazing Management}

Both allotments have grazing. Mokaac Burn was subject to winter grazing for a month. However, often the reservoir servicing the Mokaac Burn area was dry, and the area was often unused, but in years with snow or when water was in the reservoir, the area was grazed lightly. Link Spring's Tweedie pasture was under a 3-pasture deferred-rotation system, its trend reading area is one-half mile from water, and use has been heavy $(50 \%+)$ in low-production years and light (30\%) on years of greater red brome production. The Bench was grazed from October to June, and the forage-use studies through the 1990s and 2000s were all in the light cattle use (20-40\%) category.

\section{Conclusion}

Letting wildfires burn in the sagebrush, pinyon-juniper, and blackbrush was not a recipe for a landscape of little more than annual bromegrasses and weeds, with or without seed-

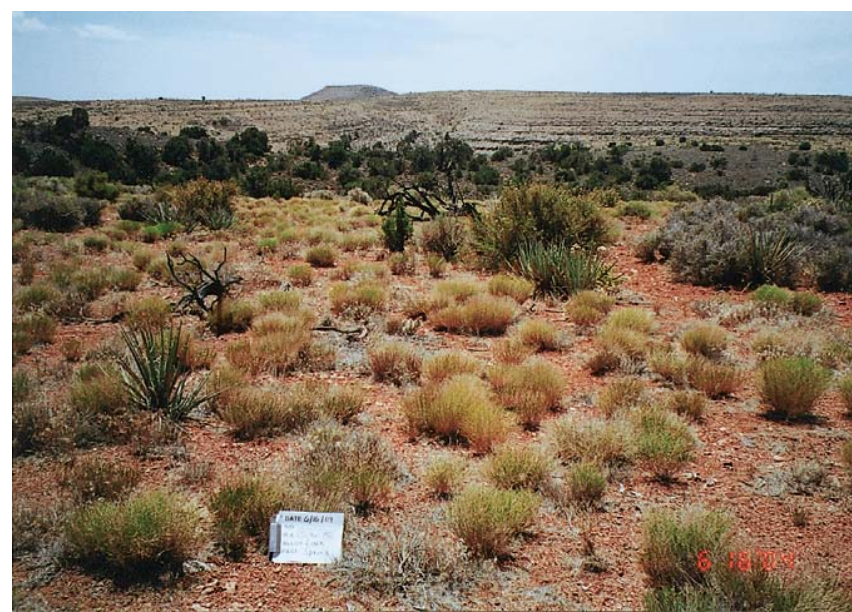

Photo 4. Link Spring Bench Fire, in 2004. Note the increase in shrubs and loss of seeded grasses. Annual bromegrass is also present. Precipitation in 2003 was $67 \%$ of average.

ing after the fire. All burns occurred in a mosaic pattern in the sagebrush, blackbrush, and sagebrush, all of which was desirable. Perennials in the arid environ have slowly returned to their dominance, albeit by a small margin in some transects. Annuals slowly became less prevalent, after 15-20 years, but perennials have shown a dramatic increase in all transects.

I believe seeding efforts should be held in abeyance until such wet cycle events as E1 Niños return and then have the seed flown on, instead of seeding in dry cycles just because an area has burned recently. In that time, it can be observed what native plants have returned or are starting to return and allow them grow to their potential before putting more plant competition into the system.

Preventing reburns in previously burned areas is where suppression efforts need to be concentrated. Fire suppression needs to be done in recently burned areas to allow plant community succession to progress, until fire entry is needed to keep the plant community in a desired state.

Author is an Ecologist with the Bureau of Land Management, St.George, UT 84790, lee_hughes@blm.gov.Disclaimer: The views expressed in this article are the author's and not that of the Bureau of Land Management. 